Accepted for Publication in Journal of Social Policy, March 2019

\title{
Children and their Rights and Entitlements in EU Welfare States
}

Mary Daly, University of Oxford

\begin{abstract}
We need better classifications and a more nuanced understanding of policy approaches to children. This paper reviews some of the existing conceptualisations and the latest relevant policy developments and develops an analytic framework for further research. The article takes an EU-wide approach to examine developments in income support policy, parenting-related leaves, early childhood education and care and children's right to participation to see what they reveal about prevailing approaches to children. The paper identifies some strong moves towards a greater focus on children in social policy but suggests differentiating between three different approaches: family oriented, childhood oriented and child oriented. These approaches differ in terms of whether their primary focus is on children or adults, whether they engage with children directly or indirectly, the set of entitlements involved and the desired outcome.
\end{abstract}

Analysing policy through a child-focused approach is a potentially powerful lens to identify trends and undertake critical review. It is also crucial given the heightened policy activity around children and the suggestion that we may have attained child-centredness in law and family life (Therborn 1993; Wyness 2014). There are some compelling signs. The UN Convention on the Rights of the Child (UNCRC) - enacted in 1989 - has been a lodestar for the rethinking and modernising of many of the policies and institutions that deal with children and families (Lundy et al, 2013). The EU, too, is mobilising its member states to develop childfocused social and educational policies in the service of its 2013 Recommendation on Investing in Children and commitments around children's human rights (European Commission 2013a; European Parliament, Council and Commission 2007). A further spur in the child-centred direction is the turn to social investment as a rationale for policy reform - its orientation towards the development of human capital especially prioritises widespread provision of early childhood education and care services (ECEC) (Morel et al 2012). This contribution steps back from claims around contemporary policy as child-centred, and suggests the need to: (a) probe both the different approaches to children present in contemporary social policy in the EU member states and the signature movements in particular directions; (b) identify and differentiate the main concerns and approaches. At the paper's heart is the following question: What are the main developments in child-related social policy in the EU member states and what underlying approaches can be discerned?

The article is an attempt to think through and investigate some of the complex issues involved and crystallise the meaning(s) of 'child-centredness' from a policy perspective. As policy develops so too must our classifications of it. At the minimum, we need precision and clarity in the terms and theorisations we employ. Existing scholarship will be expanded in several respects. The article intends, first, to offer a way of classifying developments in social policy from a child-focused perspective (this and other terms are used relatively loosely at this stage). Secondly - and relatedly - we expand upon the notion of 'child-centredness' and related concepts in social policy and elaborate further the tensions and dilemmas associated with childrelated social policy. Thirdly, the article is EU-wide in its scope, thereby adding to our knowledge of dominant trends across countries by encompassing a breadth of perspectives and empirical developments. In all of this, and finally, we seek to bring together insights from a 
range of disciplines - social policy, law, sociology, social work/child protection. The overarching challenge is to develop a framework for policy analysis that recognises and understands children as having their own personhood and agency, whilst also being able to identify policies that fashion child policy as serving the reproduction of both collective institutions and the adult world.

To answer the research question the article undertakes three exercises. The first opens up the matter of how to conceive of child policy, drawing from some existing literature to identify the intersecting strands of thought. From this first section we develop a series of lines of analysis/questions which then guide the second part in reviewing recent policy developments. This is envisaged as a kind of sensitising analysis rather than an explicit stocktaking. For it we go broader than the usual understanding of social policy, examining the classic child and family relevant policy measures - income support for families with children, parenting-related leaves, ECEC - as well as developments around children's human rights and participation. The third exercise (in the paper's last part) reflects upon the key developments and elaborates an analytical framework which identifies different policy approaches. For its evidence, the paper relies on overview assessments carried out at national and EU levels and on EU and other databases (Eurydice, MISSOC, OECD). The time period is the last ten years. The EU-wide focus (rather than particular country comparisons) has the advantage of providing an overview but it also means that we look at developments in broad strokes. For the purposes of analysis we follow the UNCRC and define children as those below the age of 18 years unless, under the law applicable to the child, majority is attained earlier.

\section{Conceptualising the Field}

There is a large literature on children, childhood, law, policy and society; limitations of space permit us only to overview this work for the purpose of sketching out signature lines of analysis. We look briefly in turn at different ways in which the relationship between children and social policy has been conceived and analyses of policy evolution.

The literature offers a number of conceptions of the relationship between children and policy. One strand of work frames children in the context of family, seeing the resultant policy approach as closely associated with family- and gender-related values and politics (e.g., Lewis 2006). Secondly, there is a body of work on children's condition or situation, often conceived in terms of policy outcomes and relative weaknesses in that regard. Child poverty features strongly here for example - with its focus on the nature of childhood adversity and material deprivation (e.g., Ridge 2002) - but so too does the more universalistic but subjective concept of child-wellbeing (e.g,. Axford 2009). Another prominent way of framing the relationship is in terms of children's rights and entitlements (Lister 2007; Tisdall 2015; Heimer and Palme 2016; Waldock 2016). This literature looks towards the legal field but there is also a growing body of work on children's rights in social policy (e.g., Lister 2003). The complexity of a rights perspective as applied to children is a prominent theme (Mayall 2000; Lister 2007). A fourth relevant set of literature focuses on the changing nature of childhood and the place of the child in society (e.g., Qvortrup 1994; Wyness 2006; Tisdall and Punch 2012). Emphasising childhood as socially constructed, children as a distinct social/population group and children's agency, a differentiation is made between meeting children's needs (in which children are treated as generally passive and parents are the arbiters of children's needs) and enabling children's agency (in which children are subjects and agents) (Axford 2009). This literature sensitises us to the specificity of the child's world and the potential for contest and even conflict between that and the adult world. This field has had considerable impact, although not particularly in social policy. Thinking about its potential application underlines the need to 
accord 'conceptual autonomy' to children, especially analytically uncoupling them from the family and adult institutions (Strandell 2010: 168) and to adopt a perspective capable of placing the child at the centre (Waldock 2016). An underlying thread is the extent to which policy grants recognition to children and their worlds.

When we turn to the literature on the evolution of the treatment of children in law and public policy (Ariès 1962; Daniel and Ivatts 1998; Therborn 1993), the story told is one of complexity and rather slow change. Therborn (1993) has identified two pivotal trends associated with childhood and children as concerns of public policy: the constitution and emancipation of childhood. With the former he is referring to how a changing legal situation served to define and redefine childhood and children. By 'emancipation' he means the process whereby children's rights were expanded vis-à-vis those of parents and adult institutions, generally loosening adult controls and constraints on children. Key drivers here were the establishment of the principle of equal parenthood between mothers and fathers and the increasing weight given to the principle of the child's best interests in cases of family litigation (Therborn 1993; Wyness 2014). While Therborn is not always clear about the difference, it is important not to elide developments relating to children as a social group and childhood as a social institution and phase of the life course.

A crucial insight from both literatures is that, historically, the family and family law tended to be the guiding influences on all matters to do with children; as Therborn (1996: 36) puts it 'the child' had to emerge from under the shadow of 'the family' for a child-oriented policy to exist. This points especially to the role and view of the family that exists in society and how this penetrates law and policy (Millar and Warman 1996; Daly 2010; Strandell 2010). Social policy has generally been slow to recognise children as individuals and/or as social rights' holders, for long oriented to family-related and paternalistic functions (Kamerman and Kahn 1978; Gauthier 1996). Factors exerting an influence on progress in this regard include how valued the family is as an institution and way of life, perceptions of the appropriate type of family and degree of state intervention in family life and the particular notions that prevail in regard to the place of children in society (Skevik 2003; Mätzke and Ostner 2010; Wyness 2014). We may draw the conclusion that a more child-centred perspective opposes a singular focus on the family which risks rendering children invisible. The popular frame of familialisation/individualisation suggests itself as an analytic tool, but we need to be careful with such terms since they are contested (Lohmann and Zagel 2016) and have a highly constrained application to children (not just because they derive from an adult model but also because legally children are minors and the dependants of their parents). Instead of familialisation/individualisation, we work with a looser framing around the degree to which children (and their 'problems') are located within a familial context and purview. The underlying set of references is to family and parenthood as institutions of child welfare.

If policy does not locate children within the family and parenthood then where? We suggest two other possible policy foci: childhood and children. Childhood has a structural reference, relating closely to life course as a generational structure or part of a generational order. This perspective conveys the notion of life as a sequence of organised stages based on the temporal patterning of biography which interlinks economic and social roles and relationships, cultural expectations and legal obligations and claims (Daly 2018). When applied to social policy, the focus is placed on policy's role in shaping and resourcing both the typical organisation of different life-course phases and transitions and the inter-connections between them. Among many possible examples are the standardisation of schooling systems or the use of age and status-related conditions for the purpose of receiving income support or services (Leisering and 
Leibfried 1999). This suggests that the relationship between childhood and adulthood as institutionalised life phases is cardinal for the analysis to be undertaken here - When does one end and the other begin? What public resource-related claims are accorded to each and how are their claims connected? The social investment approach has something to say on these questions; it argues for modifying the existing opportunity structures attaching to different life course stages and especially for shifting resources to the earliest phases of life through investments in children's human capital (Esping-Andersen 2002; Hemerijck 2015; European Commission 2017). A second line of investigation for the present purposes, therefore, concerns the degree to which policy emphasises childhood and its resourcing as a phase of life.

The third possible policy focus is the child or children. Core here is the extent to which the child as a person and/or children as a social group or category of actors are foregrounded by policy, as distinct from the social institutions and relations that constitute either family or childhood. While difficult to disentangle it is helpful to query whether policy recognises children in their own right (rather than locating them within the family) and how far policy extends to granting children resources and enabling their agency. Rights constitute a central concept in both regards. The UNCRC is a classic reference here, arguably the fullest statement yet of children's rights. The Convention's approach to children and their rights can be thought of in terms of two levels. A first is the set of welfare-related rights enunciated for children: the right to sustenance (Article 6), the right to health care (Article 24), the right to social security (Article 26), the right to a sufficient standard of living adequate for physical, mental, moral and social development (Article 27) and the right to education (Articles 28 and 29). Here the child is the obect of rights and/or policy, although it must be emphasised that the Convention is also a charter for parents, assigning them significant rights and responsibilities as children's guardians and creating a potential tension between the rights granted to parents and children (Lansdown 2005). In what can be regarded as a second level, the UN Convention enunciates four general principles to be taken into account in all efforts aimed at child rights' implementation, including the best interests of the child (Article 3(1)) and the child's right to participation in all matters affecting her or him (Article 12). ${ }^{1}$ The latter turns the spotlight on procedures that facilitate children's agency, participation and even 'voice' (Collins 2017). While there is considerable dispute about the view taken by the Convention of children and their rights (Wyness 2006; Rehfeld 2011; Tisdall and Punch 2012), the relevant literature here - especially that on children's participation (e.g., Percy-Smith and Thomas 2009; Lansdown 2011) and children's citizenship (Lister 2007; James 2011) - underlines that the realisation of children's rights involves resources and the capacity for participation. Agency, one of the most complex concepts in the social science lexicon, needs to be pinned down in relation to children who are generally seen as having only constrained capacity for agency, especially when very young (Esser et al 2016). To pin it down, we suggest thinking of it as something as achieved (rather than as a state or property) and as requiring from policy certain resources. The possible resources include: recognition, access to income and services, and opportunities for participation that enable their autonomy. To take these points forward, two fundamental clarifications are helpful. First, when examining the relationship between children and social policy and the extent to which children are present in and focused upon by policy, we should think in terms of children as potential policy objects and/or subjects. Secondly, it is fundamental to examine the degree to which policy confers children with recognition, income and services as well as opportunities for participation.

\footnotetext{
${ }^{1}$ The other two are the child's right to non-discrimination (Article 2) and the child's right to life, survival and development (Article 6).
} 
These insights lead to several key questions that can guide the analysis to follow:

$>$ To what degree does policy locate children and their welfare within a familial context?

$>$ To what degree is policy aiming at resourcing childhood (as distinct from children)?

$>$ To what degree is there a focus on children in terms either of recognition of their status as members of a group and/or granting them resources and participation that enable personal autonomy?

Informed by the foregoing discussion and line of questioning, we now take a reading of recent policy developments. As mentioned, we will be examining cross-national evidence produced in the context of policy reviews (especially associated with the EU) as well as the relevant national and regional studies of general trends. We should stress that we expect policies to vary, to lean in different directions and to be characterised by more than one major approach. It should also be noted that we use the above questions in a general way as sensitising probes. Hence their purpose is to signify tendencies and matters of degree rather than providing absolute answers.

\section{Insights from Examining Relevant Family Policy Provision}

\section{Child and Family Income Support}

Child-related income and tax allowances are the classic benefits here. Historically, eliminating family poverty and hardship and equalising income between families and other sectors of the population was a widespread motivation for the introduction of child-related financial transfers (Kamerman and Kahn 1979). In some countries the spotlight was trained especially on the most needy sectors of society (such as necessitous mothers, widows and orphans) whilst in others the male wage earner as pater familias was the target (Wennemo 1994). To what extent are there moves to foreground children and/or childhood in income supports for families? A key barometer here is whether 'children' are engaged with directly by policy makers, in particular whether they are given access to resources and/or opportunities for participation. The evidence suggests not with income benefits generally targeting parents and constructed around need understood as a characteristic of adults and families (Frazer and Marlier 2017). There are a few exceptions, though.

One such exceptional case to note is where 'children' personally receive cash incentives to remain on in school - here there is direct resourcing of children and also conferment of some autonomy from their parents. An example is education maintenance allowances which exist in Scotland, Wales and Northern Ireland (and formerly in England ${ }^{2}$ ), paying some $£ 30$ a week on a means-tested basis directly to young people aged between 16 and 19 years who remain on in school or training. There are similar instances elsewhere - in Sweden, for example, the 'child' personally receives an education study grant if s/he continues in education after age 16, at which stage the child allowance generally ceases to be paid to the parent (although some circumstances allow a continuation $)^{3}$. Given the older age targeting and the fact that similar allowances are given to young people undertaking unpaid work-based training, the extent to

\footnotetext{
${ }^{2}$ England abolished the education maintenance allowance in 2010 replacing it with a Bursary Fund which is paid to the educational institution rather than the student. See https://www.gov.uk/education-maintenance-allowanceema. For Scotland see: https://www.mygov.scot/ema/. For Wales see: https://www.studentfinancewales.co.uk/fe/information-for-parents/education-maintenance-allowance.aspx. For Northern Ireland see: https://www.nidirect.gov.uk/information-and-services/14-19-education-employment-andtraining-options/education-maintenance-allowance

${ }^{3}$ See https://www.government.se/government-policy/education-and-research/the-swedish-financial-aid-systemfor-studies/
} 
which this can be said to be a direct social policy benefit to 'children' is qualified. That said, the existence of such benefits is significant because the 'child' is granted a beneficiary status as well as some financial autonomy and the benefits act to delimit the period of childhood.

This type of measure shows that it is possible for policy to consider 'children' autonomously and even to grant them benefits directly, although this is governed by an age threshold which demarcates youth from younger children. Other than this, there are no known income benefits paid directly to children in EU member states and no movement in that regard. Of course, social policy is constrained here by virtue of family law which generally obliges parents to support their children and limits imposed on autonomy by virtue of age and capacity. And this is the view that seems to prevail, especially if judged by the policies that push in the other direction and act to extend the period of 'childhood' and dependency. We refer here to provisions whereby parents continue to receive child benefits and/or tax allowances for a 'child' who is in education or training beyond the age of 18 . This is the norm and is why we have represented the more independence-oriented, child-related provisions outlined above as exceptional. At the present time in the EU, some 19 member states pay child income support to the parent for a 'child' in education or training beyond the age of 18 and 10 pay it beyond the age of 20, with Belgium, Czech Republic, Germany, Luxembourg and Slovakia paying it up to the age of 25 . $^{4}$ These are boundary-defining benefits acting to 'fix' childhood as extending into early adulthood (and thereby mandating 'dependence' for the children and young people involved). These measures underline the family as a widespread unit of policy intent and entitlement.

Other aspects of income support policy are revealing about the questions of whether family, childhood or children are the focus of policy. Recent years have seen some significant cutbacks in levels of cash supports to families and spending in that regard (European Commission 2017). Twelve member states (mainly Eastern European and Mediterranean countries) have made major cutbacks and, between 2008 and 2012, spending on child and family income support fell in 21 out of 28 member states. The cutbacks, important in themselves, have added significance for the reforms they are introducing. Two trends are of particular note.

The first is a greater use of targeting of income supports to families. This, a strong crossnational trend, means a change in regard to which families with children are prioritised for state support - with strong moves in some countries (e.g., Greece, Poland, Portugal, Romania) to target support towards larger families or those on low incomes and, hence, away from smaller families as well as families in general (European Foundation 2015; European Commission 2017; Daly and Ferragina 2018). These reforms are not explicitly child-focused and there is no privileging of the child or her his/agency - rather the unit of conception and support is the family or household. But with an underlying dynamic of selectivity, one could read them to suggest that some children's families are considered to be more deserving than others. This is a subversion of the principle of universality which has some history in Europe as a principle of child and family policy and is a counterpole to selectivity in supporting families with children (Wennemo 1994). A second trend is towards fiscalisation of financial support to families (Ferrarini et al 2012). OECD data suggests that the average value of financial support to families through the tax system now rivals that given to families through the benefit system. ${ }^{5}$ While a fiscal policy approach - effected through tax credits and allowances for example - was and still is favoured by the UK and other liberal-oriented countries, it is increasingly found also in other parts of Europe (e.g., Austria, Belgium, Germany and Italy). As a move away from

\footnotetext{
${ }^{4}$ See https://www.missoc.org/missoc-database/comparative-tables/results/

${ }^{5}$ See http://www.oecd.org/els/soc/PF1_1_Public spending_on family benefits.pdf
} 
cash support, it portends a change in both the form and conditions under which families with children are supported financially and is at its core an attempt to more closely link child and family income support with income tax status and earnings, hence parental employment. Indirectly, it generalises a set of norms about childhood and the economic organisation of family - that children should be reared in families where one or both parents are in gainful employment for example.

\section{Parenting-related leaves}

This is one of the areas of family policy that has seen the greatest expansion and innovation in the last decade or so (Daly and Ferragina 2018). Almost all countries of the EU now have three types of such leave available: maternity, parental and paternity (European Commission 2017). While historically maternity leave was the pivotal policy to support parenting - especially to improve the health and well-being of the new mother and baby (Gauthier 1996) - there has occurred a two-fold shift in focus: from mothers to parents, and from mothers to fathers. To summarise a complex set of developments, the EU countries have seen moves to consolidate maternity leave, expand parental leave, treat the couple as the unit of entitlement for parental leave rather than the individual parent(s) and increase the availability of paid leave to fathers (either through extending paternity leave and/or making a portion of the parental leave more attractive to fathers) (Blum et al 2017). The implications for parents are obvious; those for the construction of childhood and the treatment of children less so.

At first glance, this appears very much like a child-focused development. Some research has interpreted developments in this way - Birnbaum et al (2017), for example, undertake a comparative analysis of the degree of intergenerational redistribution characterising different welfare states and interpret the parenting-related measures as evidence of redistribution towards the youngest generation (with the Nordic countries emerging as by far the most childfocused from this analysis). We suggest a more cautious approach in light of our framework which sensitises us to rather fine-grained variations. While it may seem self-evident that parenting-related leaves are intended as a measure for children, this is not necessarily so. Certainly, assumptions in the leaves can be read as framing what is good for children. In this regard, we could read the current policy consensus as assuming that child well-being and a 'good childhood' are best secured by: a) having both parents present in the first month or two, b) being cared for at home by the mother with some input from the father for about another year, and c) having access to an increasing volume of out of home ECEC from the age of 1 on. But while it seems self-evident that arrangements for parents' leave from employment centre on considerations around children, there is no evidence to prove this. Indeed, there is important counter evidence. Discursively, a range of parent-related and family considerations dominate gender equality in care-giving and employment, activating men's caregiver responsibilities, greater freedom of choice for parents, greater female employment participation (Mätzke and Ostner 2010; Brandth and Gíslason 2011). Certainly, the field has no children's rights orientation and, with the driving reform rhetoric being 'reconciliation between work and family life', it is hard to conclude other than that it is 'adult world' considerations that are to the fore with some considerations around childhood secondary. This is not to say children do not benefit from such provisions and their reform - rather, our point is that children are not necessarily to the fore.

ECEC

A growth in ECEC especially for very young children (up to age 3) is one of European social policy's strongest suits in recent years (European Commission 2013b; Daly and Ferragina 2018). On the face of it ECEC has inherent elements of being both child- and childhood- 
centred. And it is so. Key here is the growth of guarantees to ECEC for children. While such guarantees are often rhetorical or abstract, some seven EU member states now guarantee a legal right to ECEC for each child under 2 years, often immediately after the end of parental childcare leave. ${ }^{6}$ These are Denmark, Estonia, Finland, Germany, Latvia, Slovenia and Sweden. In most of these countries, the entitlement usually implies a full-time place. Other countries start the guarantee later. In Belgium, France, Hungary, Luxembourg, Malta, Spain and the UK, a place in publicly-subsidised ECEC is guaranteed from the age of 3 or a little earlier. So over half the EU member states grant children a right to ECEC. A somewhat different approach is to make attendance at ECEC compulsory - for example in Austria, Croatia, Cyprus, Greece, the Netherlands and Poland the last year of ECEC (pre-primary classes) is compulsory. Other countries adopting a compulsory approach include Bulgaria, Hungary, Latvia and Luxembourg. ${ }^{7}$ Comparing the two approaches is insightful about the nuances. While both make children the object of policy, the childcare guarantee goes further, recognising children as legitimate subjects with a claim on public resources and indeed a right that technically could be enacted (although it is not clear whether such rights are justiciable).

That said, there are a number of qualifications to be added to the notion of a childcare guarantee as being child-centred, and these again illustrate tensions and diverging orientations and priorities. First, ECEC is not always a direct right to children - in some countries (e.g., Finland) it is a right given to parents and in others - Sweden - the right to full-time childcare is conditional upon employment on the part of parents (Eydal and Rostgaard 2011). This underlines the point that childcare-related guarantees (among other policy domains) also aim at managing the distribution of employment among parents. Second, in addition to a potential tension between goals relating to parents and those relating to children, even when it comes to children ECEC has different objectives, philosophical orientations and constructions of both the child and childhood. Comparative research on Europe spotlights different root types or traditions - a focus of providing childcare for needy children on the one hand and early education as a good for all children on the other (Moss 2006; Scheiwe and Willekens 2009). In subsequent policy development, these two philosophies have become less distinct and national systems more hybrid. The Nordic countries in particular have a history of a more active engagement with both the needs of the child and the nature of a good childhood and attempt to marry the two perspectives with ECEC seen as a tool for enhancing the quality of life of the individual child and a social as well as an educational experience (Eydal and Rostgaard 2011). There is a stronger sense of the individual child here but we should be sensitive to the degree to which the over-arching reference is to (the governance of) childhood (Strandell 2010).

Here lie the roots of some of the critique of social investment - that its interest in ECEC is strategic, woven from the loom of instrumentalism, promoting ECEC because of its value in laying the foundation for early and later skill acquisition and cognitive and other forms of development (Esping-Andersen 2002). The most widely-levelled criticism is that the social investment approach draws from a developmental paradigm and treats children as 'becomings' (adults in potentia) (Lister 2003; James 2011). The counterfactual - children as 'beings' - is not always clearly articulated but there is a sense in it of policy failing to treat children as of inherent value as individuals who not only constitute a category of actors in their own right but

\footnotetext{
${ }^{6}$ See

https://webgate.ec.europa.eu/fpfis/mwikis/eurydice/images/2/26/Early_Childhood_Education_and_Care_pdf

${ }^{7}$ The remaining EU member states make up a third pole in that they neither offer a guarantee to children nor make ECEC compulsory. This is the case in Ireland, Italy, Lithuania, Romania and Slovakia.
} 
are deserving of resources, rights and agency (Brannen 1999; Strandell 2010). The point is not that children do not benefit from the measures proposed but that social investment's work in this regard is more or less done once childhood is resourced vis-à-vis other life course stages and children's life chances improved. There is much more to resourcing children than that.

\section{Rights and children's participation}

As we have seen, there is almost no movement to children's rights discernible in the policies considered to date. However, outside of social and family policy, the EU (and also member states) has a considerable set of actions relating to the protection of children's rights under the Treaty of the European Union - Article 3(3) especially focuses on the promotion of the protection of the rights of the child and there are other articles of the Treaty that also relate to children (European Parliament, Council and Commission 2007). The EU commitment to child rights is operationalised through the EU agenda on the Rights of the Child and EU action plan on human rights and democracy (European Commission 2011; Council of the European Union 2015). Both have a strong human rights focus, developed and monitored under the auspices of Directorate General Justice and Consumers, concerned especially with violence against children, children in migration situations, child trafficking, inter alia.

What about child participation-oriented measures? The EU has been active in this regard also and in its 2013 Recommendation on Investing in Children made participation one of three pillars in its anti-child poverty and social exclusion programme (the other two being access to adequate resources (via supporting parents' participation in the labour market and an optimum combination of cash and in-kind family benefits) and access to services (in which ECEC is prioritised but mention is also made of health, housing and social services as well as ending school segregation)) (European Commission 2013a). The EU has interpreted participation in a two-fold manner: supporting the participation of all children in play, recreation, sport and cultural activities; putting in place mechanisms that promote children's participation in decision-making in areas that affect their lives.

The evidence suggests slow progress in the member countries. In regard to children's participation in play and other recreational/cultural activities, a recent report assessing developments across the EU since the 2013 Recommendation found that only seven countries had improved their relevant provision, with the situation in the majority remaining unchanged (Frazer and Marlier 2017). The reported activities - such as greater funding or provision of facilities for children's recreational activities - seem to be contextual and environmental, focused on providing facilities, and therefore engaging indirectly rather than directly with children. Greater progress is reported on the second dimension with nine countries considered to have strengthened their policies and practices in relation to children's participation in decision-making in areas that affect their lives (especially by putting in place children's councils or advocacy and consultative measures for children) (Ibid). The policy fields in which children are allowed or enabled to participate vary, including care, education and justice (European Commission 2015). In contrast, fewer legal provisions exist to enable children's participation in designing, planning and evaluating wider services provided on their or others' behalf. Enabling children's participation occurs most often at city or local level (Ibid). In addition, the working definition of this aspect of participation evident across legislation is for 'children's opinions to be taken into account' - which is rather passive in nature (Ibid) and may indicate a sense of doing things for rather than with children (hence not promoting their agency). It is significant, though, that nearly all EU member states have in place some form of participatory structures for children and young people at a national level; most commonly national youth or children's councils (in all member states) or children or youth parliaments 
(in 12) (Ibid). Participation by teenage youth is what is targeted most widely here however. Looking at the field of child participation as a whole, Landown (2011) attributed lack of progress on the right of children to participation to the following factors: lack of clarity on the meaning of participation; lack of legislation establishing participation as a right; cultural barriers and adult resistance; lack of adult capacities; lack of tools for monitoring and measuring participation.

\section{An Analytic Framework}

The logic followed in this article has been to identify a series of lines of analysis and accompanying questions and then elaborate them by taking a reading of current provision and trends in four areas of relevant policy. Informed by an ontological perspective that emphasises policy as complex and multidirectional, the approach used to assess developments differentiated between family, childhood and children as policy orientations. A key underlying assumption is that all relevant policies affect children but their intent and the degree to which they prioritise one orientation over another will vary in form and import. Remember, though, that we have exercised selectivity in the policies studied; hence the claim is not that all policies affect children but rather those studied here. The aim now is to both summarise what we can say about policy developments and elaborate the lines of analysis further into a framework that can inform future research and analysis.

To return to the question with which we set out, which queried the main developments and the underlying approaches, we can draw a number of conclusions. First, the collective unit - family or household or even in some cases parents as a couple - dominates the (re)organisation of income support relating to children and a collective (and adult-oriented) approach is also prominent in parenting-related leaves. That said, there is a strong focus also on childhood as a life phase, with measures such as ECEC and some income and tax benefits encoding ideals and practices about childhood and addressing the generational distribution of resources (and opportunities) through early educational services especially. For example, a resourcing of childhood orientation is a prominent justification for the expansion of ECEC. We can divine also a focus on children as persons with entitlements - with some policy dealing directly with children (ECEC in some configurations and also some income supports) and conferring (albeit qualified) rights on the child. A child-centred approach is to be seen especially in the movement towards ECEC-related rights and guarantees for young children (and further guarantees are planned by the European Parliament to address child poverty ${ }^{8}$ ). That said, children have no rights or agency in parenting-related leaves - the beneficiaries and decision makers here are the parents. There is another set of subject-oriented measures also that seeks to engage children and/or enable their participation (in sport and cultural activities and also decision-making that affects them). These kinds of measure potentially approach the fullest sense of child-centred policy evoked here and in the literature but the evidence indicates little movement in this regard (although it must be said the evidence is limited).

Extrapolating from this and the preceding analysis, it is possible to differentiate three ideal type approaches. The most discerning criteria for identifying the ideal types are the primary focus of policy (adults or children), whether children are engaged with directly or indirectly, the nature of the entitlement granted and over-arching goal (see Figure 1). We should clarify that we are not claiming these as unconnected policy orientations or approaches; they shade into

\footnotetext{
8 Voted on $24^{\text {th }}$ November 2015; see http://www.europarl.europa.eu/sides/getDoc.do?pubRef=//EP//TEXT+TA+P8-TA-2015-0401+0+DOC+XML+V0//EN
} 
each other and in this and other ways allow for the possibility of policy moving in several directions at once.

The first approach we term family focused - it views children's welfare as best obtained within a family/collective unit orientation. Here there is no direct engagement with children; the focus is rather on the adult world (institutions, actors and behaviour) and to the extent that children's welfare and relevant exigencies are considered at all they are dealt with by resourcing the family or parents and/or seeking to affect parental behaviour and institutions. Autonomy for children or even recognition are not part of the policy lexicon or mindset. Second, childhoodoriented policy prioritises resourcing childhood as a stage or phase of life. Here children are an age group or age category (albeit an increasingly differentiated one) and they are resourced as members of a generation rather than as having value and claims as persons. Third, in childoriented policy there is a direct focus on children (rather than an indirect or mediated relationship as in the former two modes). But there are two variants here. The first recognises children as members of a status group, conferring resources to them via rights and entitlements qua children and in distinction to adults. In this regard children are objects of policy, achieving a degree of autonomy, recognition and resources. The second goes further in recognising and enabling children's personhood and enhancing their agentic capacities, conferring participation opportunities to children especially in a context of powerful adult institutions and persons. Here they are treated as subjects. This is arguably the highest and hardest level to achieve (and contemporary social policy has little progress to report here). With this distinction it will be seen that we conceive of child-centredness - at face value straightforward but at root a complex idea - in terms of policy that supports children as both members of a recognised group whose needs are seen to merit a claim on public resources - allowing some autonomy from adults and institutions (Skevik 2003) - and as persons in their own right - conceptualised as subjects who construct their own consciousness and life trajectories and are capable of articulating their own needs (Brannen 1999: 143). The ultimate ideal end in the latter is children's empowerment.

Figure 1 Three Social Policy Approaches to Children

\begin{tabular}{|l|l|l|ll|}
\hline & $\begin{array}{l}\text { Family- } \\
\text { oriented }\end{array}$ & $\begin{array}{l}\text { Childhood- } \\
\text { oriented }\end{array}$ & Child-focused Childrenoriented \\
Child-centred
\end{tabular}


We recognise that there is great complexity here, both empirically and conceptually. One matter relates to the limited extent to which children can be treated as separated from their parents or the family, especially when they are young. Yet, for the purposes of an analytic framework we must theoretically admit of some separation and accept that children's interests potentially differ from those of their parents (Wyness 2014). Secondly, moves to recognise children will always be contingent - on the legal definition of childhood and the age of majority, the obligations on families and public institutions regarding children, and so forth. In addition to these concerns, there are real difficulties in recognising young children's personhood and conferring agency upon them. It is possible, though, for policy to 'manage' the matter of age, rights and agency. In the UNCRC (article 5), the concept of the evolving capacities of the child is introduced to establish the principle that, whilst children's need for protection and capacity for agency are age-associated, they (and hence policy) are not bound by age. The underlying point is not just that the 0 to 18 age span covers a number of stages but that children's capacity and competencies develop through experience, culture and levels of support rather than age alone (Lansdown 2005). A core idea here regarding agency is to understand - and foster - it as a relational concept and something to be achieved and coproduced within relationships rather than in opposition to adult structures and relationships (Esser et al 2016). To approach child-centredness then, policy might allow itself the choice of relaxing age-centric models and rely more on enabling the demonstration of capacity by a child and/or substituting a framework of individual case assessment for generic age thresholds (Lansdown 2005).

In sum, we are suggesting that a double ideal has to be reached for policy to be considered child-centred (with children present both as objects and subjects). This is to some extent an idealist position but only if we accept current age and generational hierarchies, fail to recognise a difference between family, childhood and children, view children in deficit terms and take our concept of agency from the independence underpinnings of classical liberalism. Clearly, massive cultural and policy shifts have to take place for children to be considered as full members of society. This paper has attempted to illustrate, rather than exhaust, the possibilities of the relationship between children and certain social policies. There are many ways in which the preliminary research reported here invites critical test and extension. 


\section{References}

Ariès, P. (1962), Centuries of Childhood, London: Jonathan Cape.

Axford, N. (2009), 'Child well-being through different lenses: Why concept matters', Child \& Family Social Work, 14, 372-383.

Birnbaum, S., Ferrarini, T., Nelson, K. and Palme, J. (2017), The Generational Welfare Contract: Justice, Institutions and Outcomes, Cheltenham, UK: Edward Elgar.

Blum, S., Koslowski, A. and Moss, P. (eds) (2017), $13^{\text {th }}$ International Review of Leave Policies and Related Research 2017, London: International Network on leave Policies and Research.

Brandth, B. and Gíslason, I.V. (2011), 'Family policies and the best interests of the child', in G.B. Eydal and I.V. Gíslason (eds), Parental Leave, Childcare and Gender Equality in the Nordic Countries, Copenhagen: Norden, pp. 109-145.

Brannen, J. (1999), 'Reconsidering children and childhood: Sociological and policy perspectives', in E.B. Silva and C. Smart (eds) The New Family?, London: Sage, pp. 143-158.

Collins, T.M. (2017), 'A child's right to participate: Implications for international child protection', The International Journal of Human Rights, 21, 1, 14-46.

Council of the European Union (2015), EU Action Plan on Human Rights and Democracy, Brussels: Council.

Daly, M. (2010), 'Families versus state and market', in F. Castles, S. Leibfried, J. Lewis, H. Obinger and C. Pierson (eds) The Oxford Handbook of the Welfare State, Oxford: Oxford University Press, pp. 139-151.

Daly, M. (2018), 'Generations, age and life course: Towards an integral social policy framework of analysis', Contemporary Social Science DOI: 10.1080/21582041.2018.1455107

Daly, M. and Ferragina, E. (2018), 'Family policy in high-income countries: Five decades of development', Journal of European Social Policy, 28, 3, 255-270.

Daniel, P. and Ivatts, J. (1998), Children and Social Policy, Basingstoke: Palgrave Macmillan.

Esping-Andersen, G. (2002) Why We Need a New Welfare State, Oxford: Oxford University Press.

Esser, F., Baader, M.S., Betz, T. and Hungerland, B. (eds) (2016) Reconceptualising Agency and Childhood, London: Routledge.

Eurofound (2015), Families in the Economic Crisis: Changes in Policy Measures in the EU, Dublin: Eurofound.

European Commission (2011), An EU Action Plan on the Rights of the Child, COM(2011) 60 final, Brussels: European Commission. 
European Commission (2013a), Commission Recommendation Investing in Children: Breaking the Cycle of Disadvantage, Brussels: European Commission C(2013) 778 final.

European Commission (2013b), Barcelona Objectives The Development of Childcare Facilities for Young Children in Europe with a View to Sustainable and Inclusive Growth, Brussels: European Commission.

European Commission (2015), Evaluation of Legislation, Policy and Practice on Child Participation in the European Union (EU), Final Report, Brussels: European Commission.

European Commission (2017), Taking Stock of the 2013 Recommendation on 'Investing in Children: Breaking the Cycle of Disadvantage', Commission Staff Working Document, SWD(2017) 258 final. Brussels.

European Parliament, Council and Commission (2007), Charter of Fundamental Rights of the European Union (2007/C 303/01). Official Journal of the European Union, 14.12. 2007.

Eydal, G. and Rostgaard, T. (2011), 'Day-care schemes and cash-for-care at home', in G. B. Eydal and I. V. Gíslason (2011), Parental Leave, Childcare and Gender Equality in the Nordic Countries, Copenhagen: Norden, pp. 65-107.

Ferrarini, T., Nelson, K. and Höög, H. (2012), The Fiscalization of Child Benefits in OECD Countries', GINI Discussion Paper, No. 49. Amsterdam: AIOS (Institute for Advanced Labour Studies).

Frazer, H. and Marlier, E. (2017), Progress across Europe in the Implementation of the 2013 EU Recommendation on 'Investing in Children: Breaking the Cycle of Disadvantage'. Brussels: European Commission.

Gauthier A.H. (1996), The State and the Family A Comparative Analysis of Family Policies in Industrialized Countries, Oxford: Clarendon.

Heimer, M. and Palme, J. (2016), 'Rethinking child policy post UN-convention on the Rights of the Child: Vulnerable children's welfare in Sweden', Journal of Social Policy, 45, 3, 435452.

Hemerijck, A. (2015), 'The quiet paradigm revolution of social investment', Social Politics, $22,1,242-256$.

Kamerman, S. and Kahn, A.J. (eds) (1978), Family Policy: Government and Families in Fourteen Countries, New York: Columbia University Press.

James, A. (2011), 'To be (come) or not to be (come): Understanding children's citizenship', Annals, AAPSS, 633, 167-179.

Lansdown, G. (2005), The Evolving Capacities of the Child, Innocenti Insight, Florence: UNICEF.

Lansdown, G. (2011), A Framework for Monitoring and Evaluating Children's Participation A Preparatory Draft for Piloting, London: Save the Children. 
Leisering, L. and Leibfried, S. (1999), Time and Poverty in Western Welfare States: United Germany in Perspective, Cambridge UK: Cambridge University Press.

Lewis, J. (ed) (2006), Children, Changing Families and Welfare States, Cheltenham: Edward Elgar.

Lister, R. (2003), 'Investing in the citizen-workers of the future: Transformations in citizenship and the state under New Labour', Social Policy \& Administration, 37, 5, 427-443.

Lister, R. (2007), 'Why citizenship: Where, when and how children?', Theoretical Enquiries in Law, 8, 2, 693-718.

Lohmann, H. and Zagel, H. (2016), 'Family policy in comparative perspective: The concepts and measurement of familization and defamilization', Journal of European Social Policy, 26, $1,48-65$.

Lundy, L., Kilkelly, U., Byrne, B. and Kang, J. (2013), The UN Convention on the Rights of the Child: A Study of Legal Implementation in 12 Countries, UK: UNICEF.

Mayall, B. (2000), 'The sociology of childhood in relation to children's rights', The International Journal of Children's Rights, 8, 243-59.

Marlier, E., Atkinson, A.B., Cantillon, B. and Nolan, B. (2007), The EU and Social Inclusion Facing the Challenges, Bristol: Policy Press.

Mätzke, M. and Ostner, I. (2010), 'Introduction: Change and continuity in recent family policies', Journal of European Social Policy, 20, 5, 387-98.

Millar, J. and Warman, A. (1996), Family Obligations in Europe, London: Family Policy Studies Centre.

Morel, N., Palme, J. and Palier, B. (eds) (2012), Towards a Social Investment Welfare State? Ideas, Policies and Challenges, Bristol: Policy Press.

Moss, P. (2006), 'From a childcare to a pedagogical discourse', in J. Lewis (ed) Children, Changing Families and Welfare States, Cheltenham: Edward Elgar, pp. 154-172.

Percy-Smith, B. and Thomas, N. (eds) (2009), A Handbook of Children and Young People's Participation: Perspectives from theory and practice. London: Routledge.

Prout, A. (2000), 'Childhood bodies: Construction, agency and hybridity', in A. Prout (ed.) The Body, Childhood and Society, London: Macmillan, pp. 1-18.

Qvortrup, J. (1994), 'Childhood matters: An introduction', in J. Qvortrup, M. Bardy, G. Sigritta and H. Wintersburger (eds), Childhood Matters, Social Theory, Practice and Politics, Aldershot: Avebury, pp.1-23.

Rehfeld, A. (2011), 'The child as democratic citizen', Annals, AAPSS, 633, 141-166. 
Ridge, T. (2002), Childhood Poverty and Social Exclusion: From a Child's Perspective, Bristol: Policy Press.

Scheiwe, K. and Willekens, H. (eds) (2009), Child Care and Preschool Development in Europe, Basingstoke: Palgrave Macmillan.

Skevik, A (2003), 'Children of the welfare state: Individuals with entitlements, or hidden in the family?', Journal of Social Policy, 32, 3, 423-440.

Strandell, H. (2010), 'From structure-action to politics of childhood Sociological childhood research in Finland', Current Sociology, 58, 2, 165-185.

Therborn, G. (1993), 'The politics of childhood: The rights of children in modern times', in F.G. Castles (ed) Families of Nations: Patterns of Public Policy in Western Democracies, Aldershot: Dartmouth, pp. 241-291.

Therborn, G. (1996), 'Child politics: Dimensions and perspectives', Childhood, 3, 1, 29-44.

Tisdall, E. K. M. (2015), 'Children's rights and children's wellbeing: Equivalent policy concepts?', Journal of Social Policy, 44, 4, 807-823.

Tisdall, E.K.M. and Punch, S. (2012), 'Not so 'new'? Looking critically at childhood studies', Children's Geographies, 10, 3, 249-264.

Waldock, T. (2016), 'Theorising children's rights and child welfare paradigms', International Journal of Children's Rights, 24, 304-329.

Wennemo, I. (1994), Sharing the Costs of Children Studies on the Development of Family Support in the OECD, Stockholm: Swedish Institute for Social Research.

Wyness, M. (2006), Childhood and Society An Introduction to the Sociology of Childhood, Basingstoke: Palgrave.

Wyness, M. (2014), 'Child, family and the state: Revisiting public and private realms', Sociology, 48, 1, 59-74. 